Jurnal SEMAR Vol. 7 No. 2, 2018 hal. $51-57$

ISSN: 2302-3937 | Copyright @ LPPM Universitas Sebelas Maret

Homepage: https://jurnal.uns.ac.id/jurnal-semar

\title{
NATA DE COCO, NATA DE SOYA DAN NATA DE PINA SEBAGAI PELUANG WIRAUSAHA BARU BAGI ANAK PANTI ASUHAN YATIM PUTERI DI SURAKARTA
}

\author{
Widiastuti Agustina Eko Setyowati ${ }^{\left.{ }^{*}\right)}$, Sri Mulyani ${ }^{1)}$ \\ ${ }^{1)}$ Program Studi Pendidikan Kimia Jurusan PMIPA FKIP UNS, Surakarta, 57126 \\ Keperluan Korespondensi ${ }^{*}$ : telp. 081280660500, email : \\ widiastuti_aes@staff.uns.ac.id
}

\begin{abstract}
ABSTRAK
Kegiatan pengabdian yang dilakukan adalah pelatihan keterampilan dalam memproduksi nata bagi anak-anak di Panti Asuhan Yatim Puteri Aisyiyah Cabang Kota Barat dan Panti Asuhan Yatim Puteri Aisyiyah II Kadipiro . Keterampilan ini sesuai untuk anak-anak Panti Asuhan karena metode yang digunakan sederhana, alat dan bahan mudah diperoleh dan berpotensi untuk dijadikan wirausaha baru.Metode kerja yang dilakukan meliputi : 1) uji coba pembuatan produk, 2) penyusunan modul pelatihan,3) penyediaan sarana dan prasarana berupa alat dan bahan pelatihan, 4) penyampaian materi dan pelatihan pembuatan, pemanenan dan pengemasan nata, 5) pendampingan kegiatan produksi dan pemasaran. Hasil yang dicapai dari kegiatan ini adalah : 1) Kegiatan pelatihan telah selesai dilaksanakan dan mendapatkan respon yang baik dari peserta, 2) Peserta pelatihan dapat memproduksi 3 varian nata, yaitu nata de coco, nata de soya dan nata de pina, 3) Hasil uji organoleptik meliputi aroma, warna, rasa, tekstur dan kekenyalan, didapatkan bahwa secara keseluruhan, masing-masing varian nata mempunyai tingkat kesukaan yang sama dengan nilai 5 (dalam skala 7), 4) Peserta pelatihan telah memasarkan produknya secara langsung maupun online dengan alamat instagram : @kenesnata.
\end{abstract}

Kata Kunci : nata, pelatihan, anak panti asuhan puteri, wirausaha

\section{PENDAHULUAN}

Pelatihan keterampilan merupakan salah satu cara yang dapat dilakukan dalam rangka meningkatkan kecakapan hidup. Panti Asuhan Yatim Putri Aisyiyah II Kadipiro dan Panti Asuhan Yatim Puteri Aisyiyah Cabang Kota Barat menitikberatkan kegiatannya pada bidang pendidikan. Kedua Panti Asuhan tersebut tidak memiliki program kegiatan berupa keterampilan bagi anak asuhnya.

Berkaitan dengan permasalahan tersebut, tim pengabdian melakukan kegiatan pelatihan keterampilan bagi anak-anak yatim piatu di kedua panti asuhan tersebut. Keterampilan yang diberikan berupa cara pengolahan bahan makanan dengan teknik fermentasi, yaitu pembuatan nata de coco, nata de soya dan nata de pina. Keterampilan membuat nata de coco, nata de soya dan nata de pina ini sesuai untuk anak- anak Panti Asuhan karena metode yang digunakan sederhana, alat dan bahan mudah diperoleh dan tidak membutuhkan waktu khusus, sehingga dapat dilakukan utuk mengisi waktu luang dengan kegiatan yang bermanfaat, khususnya dalam mengembangkan kecakapan hidup bekerja (occupational skill) mereka.

Nata merupakan produk yang memiliki kadar serat tinggi. Serat yang terkandung dalam nata meliputi selulosa, hemiselulosa, lignin, dan serat larut air. Dengan kandungan tersebut, nata berguna untuk minimalkan dan mencegah penyakit 
Jurnal SEMAR Vol. 7 No. 2, 2018 hal. $51-57$

ISSN: 2302-3937 | Copyright (C) LPPM Universitas Sebelas Maret Homepage: https://jurnal.uns.ac.id/jurnal-semar

yang berkaitan dengan kandungan serat yang tinggi, seperti kolesterol dan kanker kolekteral (Babio, N., dkk., 2010). Selain itu serat pada nata berfungsi untuk menurunkan profil glukosa pada penderita diabetes mellitus, mencegah konstipasi dan obesitas. Melihat manfaatnya yang demikian besar bagi kesehatan, pembuatan nata merupakan alternatif usaha yang cukup menjanjikan. Disamping proses pembuatannya yang mudah dan murah, nata dapat dibuat dari berbagai macam bahan baku yang umum, sehingga produk yang dihasilkan juga bervariasi. Nata de coco terbuat dari air kelapa (Misgiyarta, 2007) nata de soya dibuat dari limbah cair tahu, dan nata de pina dibuat dari sari nanas (Azhari dkk, 2015).

Selain air kelapa, limbah tahu dan nanas sebagai bahan dasar, dalam pembuatan nata juga diperlukan bakteri sebagai starter, karbon dan nitrogen. Starter merupakan biakan murni dari bakteri Acetobacter Xylinum yang berada dalam kondisi istirahat dan belum terkontaminasi mikroorganisme lainnya. A. Xylinum membutuhkan gula untuk dapat berkembang dengan baik. Limbah cair tahu, air kelapa dan nanas mengandung gula yang diperlukan, tetapi kadarnya masih dianggap kurang. Oleh karena itu perlu ditambahkan gula pasir sebagai nutrisi (sumber karbon) dengan jumlah yang sesuai. Kebutuhan akan nitrogen sebagai nutrisi yang lain didapatkan dari urea. Urea mengandung nitrogen yang berfungsi sebagai nutrisi untuk pertumbuhan bakteri. Selain ZA, dapat digunakan sumber nitrogen yang lain seperti kedelai dan air rebusannya, air kelapa, air beras atau cucian beras, namun bahan-bahan tersebut lebih mahal dari segi ekonomi.

\section{METODOLOGI}

Kegiatan ini dibagi dalam beberapa tahap sebagai berikut :

a) Tahap persiapan : Koordinasi dengan mitra, pembuatan sampel produk, uji organoleptik, uji kandungan serat, persiapan alat dan bahan, pembuatan modul

b) Pelaksanaan : penyampaian materi, praktek pembuatan nata, pemanenan dan pemasakan, pengemasan, pelabelan, strategi pemasaran produk

c) Evaluasi dan pendampingan pasca pelatihan

\section{Pembuatan Nata}

\section{Bahan}
a. Air Kelapa
b. Limbah Cair Tahu
c. Kulit, mata dan hari buah nanas
d. Starter Nata berupa biakan murni bakteri Acetobacter Xylinum
e. Gula Pasir
f. Urea
g. Air

2. Alat
a. Kompor
b. Panci
c. Blender
d. Pengaduk
e. Cetakan / Toples lebar
f. Gelas Ukur
g. Timbangan 
Jurnal SEMAR Vol. 7 No. 2, 2018 hal. 51 - 57

ISSN: 2302-3937 | Copyright @ LPPM Universitas Sebelas Maret Homepage: https://jurnal.uns.ac.id/jurnal-semar

h. $\mathrm{pH}$ meter

1. Mesin sealer

3. Pembuatan Nata de coco dan nata de soya

a. $2 \mathrm{~L}$ bahan (air kelapa/limbah cair) disaring, kemudian direbus bersama 50 gram gula pasir hingga mendidih.

b. Masukkan bahan yang telah mendidih ke dalam toples/cetakan, setelah dingin, tambahkan asam cuka hingga mencapai $\mathrm{pH}$ 3-4

d. Tambahkan 6 gram urea aduk hingga larut merata

e. Masukkan $400 \mathrm{~mL}$ Acetobacter Xylinum, aduk rata (tahap inokulasi)

f. Tutup toples/cetakan menggunakan kain hingga rapat dan simpan pada suhu kamar selama 7-14 hari (masa inkubasi)

4. Pembuatan Nata de pina

a. Siapkan bagian kulit, mata dan hati nanas sebanyak $0,5 \mathrm{Kg}$, kemudian cuci hingga bersih

b. Tambahkan air secukupnya, kemudian blender sampai halus

c. Masukkan nanas yang sudah dihaluskan ke dalam baskom, tambahkan $2 \mathrm{~L}$ air bersih, kemudian saring untuk mendapatkan sarinya

d. Rebus sari nanas bersama 50 gram gula pasir hingga mendidih.

e. Masukkan air nanas yang telah mendidih ke dalam toples/cetakan

f. Setelah dingin, tambahkan asam cuka hingga mencapai $\mathrm{pH}$ 3-4

g. Tambahkan 6 gram urea aduk hingga larut merata

h. Masukkan $400 \mathrm{~mL}$ Acetobacter Xylinum, aduk rata

i. Tutup toples/cetakan menggunakan kain hingga rapat dan simpan pada suhu kamar selama 7-14 hari.

\section{Tahap Pemasakan}

a. Angkat nata yang telah terbentuk

b. Cuci menggunakan air yang mengalir

c. Potong nata hingga berbentuk dadu

d. Rebus hingga mendidih, kemudian buang air rebusannya. Ulang hingga bau asamnya hilang

e. Jika bau asam telah hilang, rebus kembali nata dengan penambahan gula atau perisa buah. Nata siap untuk dikemas

\section{Tahap Pengemasan dan Pelabelan}

Produk nata dikemas dalam kemasan plastik kedap udara $(250 \mathrm{~mL})$ dan diberi stiker sebagai label sesuai dengan produk yang dihasilkan.

\section{HASIL, PEMBAHASAN DAN DAMPAK}

Kegiatan pengabdian dilakukan dalam 3 tahap, yaitu persiapan, pelaksanaan dan evaluasi. Semua kegiatan bertempat di Panti Asuhan Yatim Puteri Aisyiyah cabang Kota Barat dan Panti Asuhan Yatim Puteri Aisyiyah II Kadipiro. Diagram alir kegiatan pengabdian disajikan pada Gambar 1. 
Jurnal SEMAR Vol. 7 No. 2, 2018 hal. $51-57$

ISSN: 2302-3937 | Copyright @ LPPM Universitas Sebelas Maret Homepage: https://jurnal.uns.ac.id/jurnal-semar

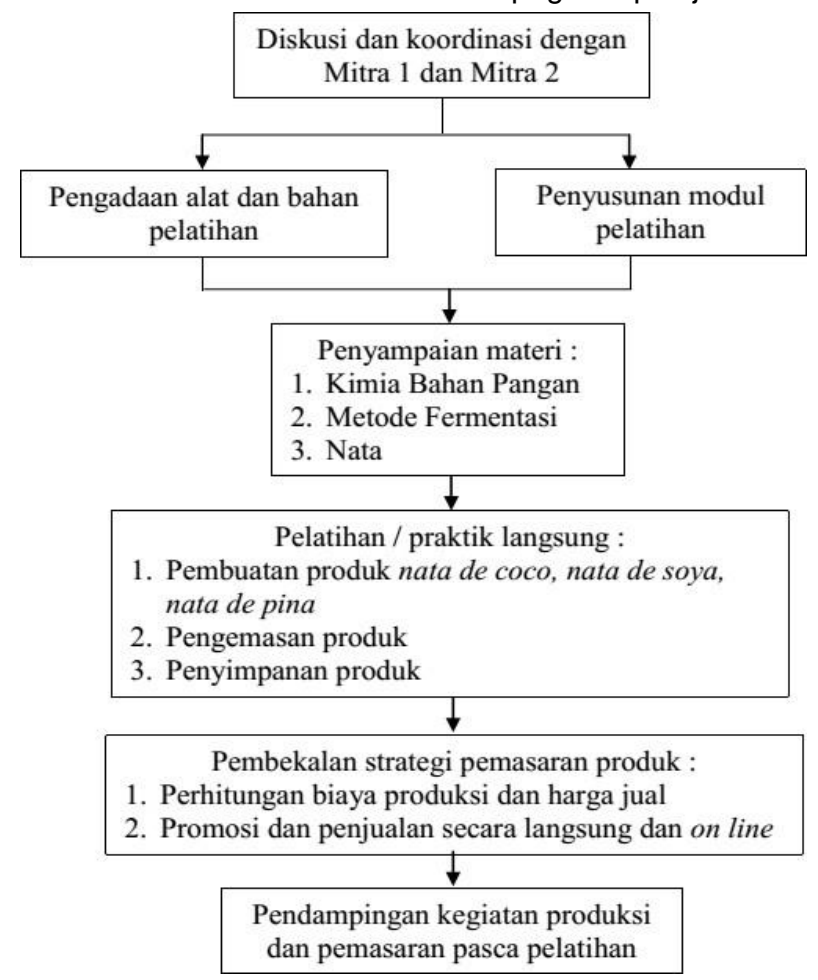

Gambar 1. Diagram alir kegiatan pengabdian

\section{A. Persiapan}

1. Koordinasi dengan kedua mitra dan diperoleh kesepakatan mengenai bentuk kegiatan, tempat dan jadwal kegiatan.

2. Uji coba Pembuatan Produk

Uji coba pembuatan produk dilakukan untuk mencari komposisi optimal yang meghasilkan nata terbaik. Dari kegiatan ini, dihasilkan produk berupa nata de coco, nata de soya dan nata pina (Gambar 1).

3. Uji Organoleptik

Uji organoleptik yang dilakukan adalah uji tingkat kesukaan (uji hedonik). Uji organoleptik dilakukan pada produk nata de pina, nata de coco dan nata de soya. Uji Organoleptik yang dilakukan meliputi parameter aroma, warna, rasa, tekstur, kekenyalan dan overall, dilakukan pada 20 panelis tidak terlatih. Data organoleptis ditunjukkan pada Tabel 1. 
Jurnal SEMAR Vol. 7 No. 2, 2018 hal. 51 - 57

ISSN: 2302-3937 | Copyright (C LPPM Universitas Sebelas Maret Homepage: https://jurnal.uns.ac.id/jurnal-semar

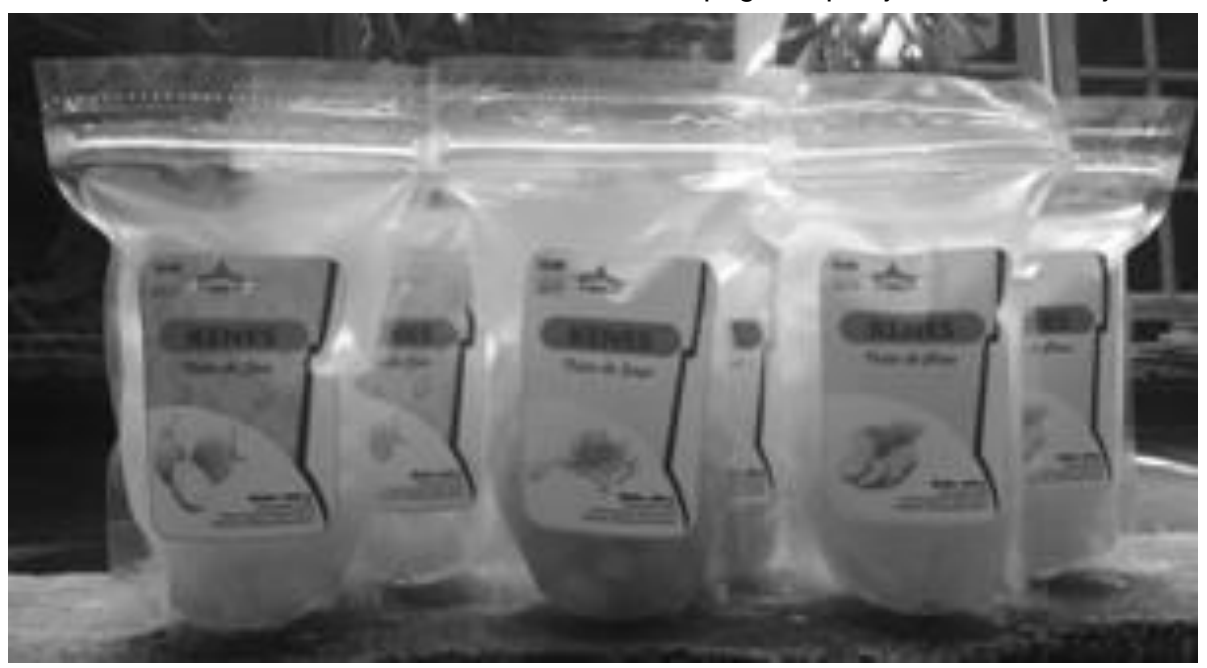

Gambar 1. Produk nata de coco, nata de soya dan nata de pina

Tabel 1. Hasil Uji organoleptik

\begin{tabular}{|c|c|c|c|c|c|c|}
\hline \multirow{2}{*}{ Sampel } & \multicolumn{6}{|c|}{ Uji } \\
\cline { 2 - 7 } & $\begin{array}{c}\text { Arom } \\
\mathbf{a}\end{array}$ & $\begin{array}{c}\text { Warn } \\
\mathbf{a}\end{array}$ & Rasa & $\begin{array}{c}\text { Tekstu } \\
\mathbf{r}\end{array}$ & $\begin{array}{c}\text { Kekenyala } \\
\mathbf{n}\end{array}$ & $\begin{array}{c}\text { Overal } \\
\mathbf{l}\end{array}$ \\
\hline $\mathrm{A}$ & 4,7 & 4 & 4,7 & 5 & 4 & 5 \\
\hline $\mathrm{B}$ & 4,7 & 4 & 5,6 & 5 & 5 & 5 \\
\hline $\mathrm{C}$ & 4,7 & 4 & 4,9 & 5 & 5 & 5 \\
\hline
\end{tabular}

Keterangan :

A . Nata de pina

B . Nata de coco

C. Nata de soya

Skala tingkat kesukaan :

1. sangat tidak suka

2. tidak suka

3. agak tidak suka

4. agak suka

5. suka

6. sangat suka 
Jurnal SEMAR Vol. 7 No. 2, 2018 hal. $51-57$

ISSN: 2302-3937 | Copyright @ LPPM Universitas Sebelas Maret Homepage: https://jurnal.uns.ac.id/jurnal-semar

Hasil uji organoleptik menunjukkan bahwa secara keseluruhan, masing- masing varian nata mempunyai tingkat kesukaan yang sama, yaitu dengan nilai rata-rata 5 dalam skala 6.

4. Uji kandungan serat

Uji kandungan serat dilakukan di Laboratorium Pangan dan Gizi Fakultas Pertanian UNS dengan metode analisis hidrolisis asam kuat- basa kuat. Hasil uji menunjukkan bahwa semua varian nata yang diujikan memenuhi standar SNI 01- 4317-1996 mengenai produk nata dalam kemasan untuk parameter kandungan serat kasar $(<4,5$ $\%$ wb).

5. Persiapan alat dan bahan

Pembelian dan persiapan alat dan bahan dilaksanakan secara bertahap sampai pada saat pelaksanaan pelatihan

6. Pembuatan modul pelatihan

Modul pelatihan dengan judul "Nata de coco, nata de soya dan nata de pina Sebagai Peluang Wirausaha Mandiri” telah disusun dan dicetak secara mandiri dan didistribusikan kepada peserta untuk digunakan pada saat pelatihan.

\section{B. Pelaksanaan}

Kegiatan pelatihan dalam rangka pembuatan nata telah terlaksana pada tanggal 11 Agustus 2017 di PAYPA Cabang Kotabarat dengan jumlah peserta 30 orang dan tanggal 26 Agustus 2017 di PAYPA II Kadipiro dengan jumlah peserta 23 orang. Pada awal kegiatan, dilakukan penyampaian materi mengenai teknologi ferrmentasi, terutama dalam hal pembuatan nata, disampaikan oleh Dr. rer. nat. Sri Mulyani, M.Si. Selanjutnya pelatihan pembuatan nata dipandu oleh Widiastuti Agustina E.S, S.Si., M.Si. Pada saat pelatihan, peserta dibagi ke dalam 3 kelompok dan masing- kelompok melakukan praktek pembuatan nata de coco, nata de soya dan nata de pina secara langsung dengan didampingi tim pengabdi. Pada kegiatan ini Tim Pengabdi dibantu oleh dua orang mahasiswa Prodi Pendidikan Kimia.

Kegiatan pelatihan tahap 2 dilaksanakan pada tanggal 24 Agustus 2017 di PAYPA Cabang Kota Barat dan tanggal 9 September 2017 di PAYPA II Kadipiro. Agenda pelatihan tahap 2 adalah pemanenan nata, pengemasan, pelabelan dan strategi pemasaran. Pada tahap ini, semua kelompok telah berhasil membuat nata dengan baik. Produk nata yang dihasilkan tebal, berwarna putih kecoklatan dan rapat (tidak ada lubang) yang menunjukkan bahwa nata yang dihasilkan bagus dan tidak terjadi kontaminasi bakteri. Nata yang dihasilkan dikemas dan diberi label sesuai dengan produknya. Pada akhir kegiatan, dilakukan serah terima peralatan kepada pihak panti asuhan.

\section{Evaluasi}

Kegiatan evaluasi dan pendampingan dilakukan secara gabungan antara 2 mitra. Pada tahap ini tidak semua peserta pelatihan ikut serta, tetapi hanya bagi mereka yang berminat dan mampu untuk mengembangkan bekal yang diperoleh dalam pelatihan menjadi wirausaha mandiri. Peserta pendampingan bekerja dalam 1 tim, telah melakukan kegiatan produksi dan penjualan secara mandiri, didampingi 3 mahasiswa dari UNS. Produk yang dihasilkan dijual secara langsung dan online melalui instagram dengan alamat @kenesnata. 
Jurnal SEMAR Vol. 7 No. 2, 2018 hal. $51-57$

ISSN: 2302-3937 | Copyright (C LPPM Universitas Sebelas Maret Homepage: https://jurnal.uns.ac.id/jurnal-semar

\section{KESIMPULAN}

1. Kegiatan pelatihan keterampilan pembuatan nata telah terlaksana di PAYPA Cabang Kota Barat dan PAYPA II Kadipiro dan mendapat tanggapan yang baik dari para peserta.

2. Peserta pelatihan dapat memproduksi 3 varian nata, yaitu nata de coco, nata de soya dan nata de pina

3. Hasil uji organoleptik meliputi aroma, warna, rasa, tekstur dan kekenyalan, didapatkan bahwa secara keseluruhan, masing-masing varian nata mempunyai tingkat kesukaan yang sama dengan nilai 5 (dalam skala 7)

4. Peserta pelatihan telah memasarkan produknya secara langsung maupun online dengan alamat instagram : @ kenesnata.

\section{DAFTAR PUSTAKA}

Ardiansyah dkk,. 2003. Pemanfaatan Kulit Nenas (Ananas comosus L.) sebagai Bahan Baku dalam Pengolahan Natadepina. Prosiding Seminar Nasional Peranan Industri dalam Pembangunan Produk Pangan Indonesia. PATPI Yogyakarta

Babio, N., Balanza, R., Basulto, J., Bullo, M dan Salas-Salvado., J. 2010. Dietary fibre: influence on body weight, glycemic control and plasma cholesterol profile. Nutr Hosp. 2010;25(3):327-340

Iskandar, Zaki, M., Mulyati, S., Fathanah, U., Sari, I., Juchairawati, 2010. Pembuatan Film Selulosa dari Nata de Pina. Jurnal Rekayasa Kimia dan Lingkungan. Vol. 7, No. 3, hal. 105-111.

Palungkun, R, 1993. Aneka Produk Olahan Kelapa. Penebar Swadaya Jakarta.

Pambayun, R. 2002. Teknologi Pengolahan Nata de Coco. Kanisius Yokyakarta

Rossi, E., Pato, U.,Damanik, S.R., 2008. Optimalisasi pemberian ammonium sulfat terhadap produksi nata de banana skin. Sagu Vol. 7 No. 2: 30-36.

Sutarminingsih, L. 2004. Peluang Usaha Nata De Coco . Kanisius. Yogyakarta 